\title{
Sexual Dimorphism in Anthonomus santacruzi (Coleoptera: Curculionidae): a Biological Control Agent of Solanum mauritianum Scopoli (Solanaceae)
}

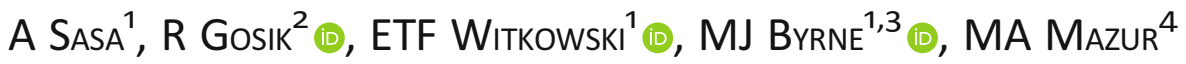 \\ ${ }^{1}$ School of Animal, Plant \& Environmental Sciences, Univ. of the Witwatersrand, Johannesburg, South Africa \\ ${ }^{2}$ Dept. of Zoology and Nature Protection, Maria Curie-Skłodowska University, Lublin, Poland \\ ${ }^{3}$ DST-NRF Centre of Excellence for Invasion Biology, School of Animal, Plant \& Environmental Sciences, Univ. of the Witwatersrand, \\ Johannesburg, South Africa \\ ${ }^{4}$ Institute of Biology, Univ. of Opole, Opole, Poland
}

\section{Keywords}

Biocontrol, invasive plant, morphometry, sex determination, sexual dimorphism, South Africa

\section{Correspondence}

Miłosz A. Mazur, Institute of Biology, Univ. of Opole, Oleska 22, 45-052 Opole, Poland; mazurmilosz@gmail.com

Edited by André VL Freitas - UNICAMP

Received 8 January 2020 and accepted 5 June 2020

Published online: 16 July 2020

(C) The Author(s) 2020

\begin{abstract}
There is evident variation in body size amongst Anthonomus santacruzi Hustache, 1924, weevils. The aims of this study were to assess if the variation in body size in $A$. santacruzi weevils is a result of sexual dimorphism and what features can be used to distinguish males from females. The weevils were collected from field sites in Mpumalanga, South Africa, where they were introduced as biocontrol agents of Solanum mauritianum Scopoli. Body structures and the presence/absence of the tergal notch was examined under an optical stereomicroscope and SEM to assess differences between sexes. The morphometric analysis of the body structures included rostrum length (base-apex and antennal insertion-apex), elytral length and width, pronotum length and width, first tarsus length, first tibia length, funiculus length and total body length. Rostrum length, elytra length and width and total body length were significantly larger in females than in males. A tergal notch in the 8th abdominal tergite was present in males and absent in females. The body structure; of rostrum length, elytra length and width and total body length overlapped between sexes in some specimens. The abdominal tergal notch was found to be the most useful body structure to distinguish males from females in A. santacruzi.
\end{abstract}

\section{Introduction}

Anthonomus Germar, 1817 (Coleoptera: Curculionidae) is a weevil genus containing more than 500 species, distributed predominantly in the Neotropic (over 400 species) and in the Palearctic (73 species) regions, but also in Indomalaya (9 species), the Afrotropics (3 species) and in Australasia (2 species) (Bená \& Vanin 2013; Gosik et al 2017). They develop inside buds and fruits, and the adults are known to feed on buds, flowers, fruits and young foliage of several cultivated and wild plants, resulting in premature abscission (Rodríguez Leyva et al 2007; Speranza et al 2014). Therefore, the genus includes many species of economic importance such as
Anthonomus grandis Boheman, 1843, A. eugenii Cano, 1894 and $A$. rubi (Herbst, 1795), which are regarded as serious pests (Smreczyński 1972, Ramalho \& Jesus 1988, Speranza et al 2014). On the other hand, species such as $A$. santacruzi Hustache, 1924, A. monostigma Champion, 1903, A. morticinus Clark, 1998 and $A$. sisymbrii Hustache, 1939 are used as biological control agents or being considered as potential biocontrol agents of invasive alien plants in USA, South Africa and New Zealand (King et al 2011; Chacón Madrigal et al 2012; Hakizimana and Olckers 2013; English \& Olckers 2018; Mkhize \& Olckers 2019). According to Clark \& Burke (1996), over 30 species of Anthonomus are associated with Solanaceous plants. 
Anthonomus santacruzi (flowerbud weevil) (Fig 1) is native to South America (southern Brazil, northern Argentina and Paraguay) and feeds mainly on the flowers and flower buds of Solanum mauritianum (Olckers 2011). The habitat, food and ecological preferences of $A$. santacruzi adults were described by Clark \& Burke (1996), Olckers (2003) and Mkhize and Olckers (2019), while the morphology of the immature stages was described by Gosik et al (2017). The weevil was released in South Africa in 2008 for the biological control of S. mauritianum (Olckers 2011; Fowler 2014; English \& Olckers 2018) and has established, but was subsequently rejected in New Zealand in 2013 (for non-target attacks on Solanum aviculare in quarantine (Hakizimana and Olckers 2013). S. mauritianum is a major declared weed, predominantly in the eastern higher (summer) rainfall regions of South Africa, negatively impacting agricultural lands, plantation forestry, riverine habitats and conservation

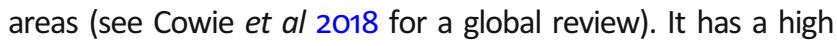
reproductive rate in terms of seed production, and dense, relatively long-lived soil seed banks, resulting in a proliferation of seedlings when released from canopy shading (Witkowski \& Garner 2008). Furthermore, mechanical clearing by cutting the stem is largely ineffective due to basal resprouting, unless the stem is cut low and the cut stump immediately treated with the appropriate herbicide (Witkowski and Garner 2008). Reducing its reproductive output through releasing appropriate biocontrol agents should be a priority. Furthermore, when releasing the agents onto selected $S$. mauritianum populations, the optimal ratio of males to females should be utilized to maximize population development and growth and hence achieve the intended control effects. The use of $A$. santacruzi as a weed biological control agent in South Africa justifies research into its biology and ecology.

Separating male and female $A$. santacruzi pupae using morphological characters other than the shape of the gonothecae is difficult (Gosik et al 2017). It was found, that female pupae (average body length $=2.76 \mathrm{~mm}$ ) were larger than male pupae (average body length $=2.52 \mathrm{~mm}$ ). However, the phenotypic variation in body size, so evident in $A$. santacruzi weevil populations, has still not been clearly verified to assess whether it is due to sexual dimorphism or only depends on variation between individual specimens, that might be related to external environmental factors such as food quality (Foelker \& Hofstetter 2014; Łukowski et al 2015). Further, recognizing the differences between sexes using external morphology is unknown for this species.

According to Dinuă et al (2009), in many cases, the two sexual forms in insects cannot be separated without analysing the genital organs. However, sexes in some species can be distinguished using secondary characters such as the body size and proportion of particular parts, the form of the antennae and oral ornaments, sculpture of the cuticle, body colour and more developed appendices in one of the sexes, as well as functional sexual characters (e.g. a large number of olfactory sensors and more developed antennae on males, or a bigger abdomen on females).

Body size is a key biological trait which is frequently used to assess fitness. Apart from sexual dimorphism, variation in body size may also stem from genetic heritability and environmental factors and have strong effects on reproduction, dispersal ability and intraspecific competition (Foelker \& Hofstetter 2014). Environmental factors such as temperature, habitat and resource food quality have been found to cause phenotypic variation in insect body sizes (Foelker \& Hofstetter 2014).

Since there is apparent variation in body size in $A$. santacruzi populations, the ability to distinguish the sexes may be important in post-release evaluation of the weevil in biological control studies. For example, in experiments which require the sex of the experimental or sampled weevils to be known (Sappington \& Spurgeon 2000). The precise estimation of the sex ratio is an important issue in ecological and biological control programs (Tabadkani et al 2012). Distinguishing sexes may also help not only in explaining the relative differences in body sizes in $A$. santacruzi but also in complementing a general gap in knowledge about the external sexual dimorphism of insects in general. Therefore, the aim of this study is to explore morphological differences between $A$. santacruzi males and females and to provide a useful tool for rapid differentiation between the sexes, both during laboratory procedures and field work.

\section{Material and Methods}

A total of 97 weevils were collected (by hand) from randomly selected S. mauritianum plants in the field in the Sabie River catchment, Mpumalanga, South Africa (GPS S25 $03^{\prime} 45.0^{\prime \prime}$, E30 $54^{\prime} 25.2^{\prime \prime}$, altitude 766 m a.s.I.) in November 2017 by A. Sasa and were immediately fixed in $75 \%$ ethanol.

To find morphological characters important for sex determination of $A$. santacruzi we assessed some of the features studied by Smreczyński (1972) on $A$. varians (Paykull, 1792), on A. pomorum by Duan et al (1999), by Sappington \& Spurgeon (2000) on $A$. grandis and on the subfamily Anthonominae by Kovarik (1983). We also assessed some characters used for sex differentiation in other weevils from different subfamilies, e.g. Hylobius warreni Wood, 1957 (Öhrn et al 2008), as well as other potentially sexually dimorphic features such as the shape of pronotum and length of the funicle.

Nine morphometric variables, namely (1) total length of the rostrum (from base to apex); (2) metarostrum (using the distance between the base of the rostrum and the insertion of the scape); (3) the length of the pronotum (measured along the medial line); (4) width of pronotum (measured at the widest part); (5) length of elytra (measured along elytral suture); (6) width of elytra (measured in the widest place); (7) length of the first tarsus (measured without the tarsal claw); (8) length of the 
Fig 1 Range in total length between male and female Anthonomus santacruzi Hustache, 1924.

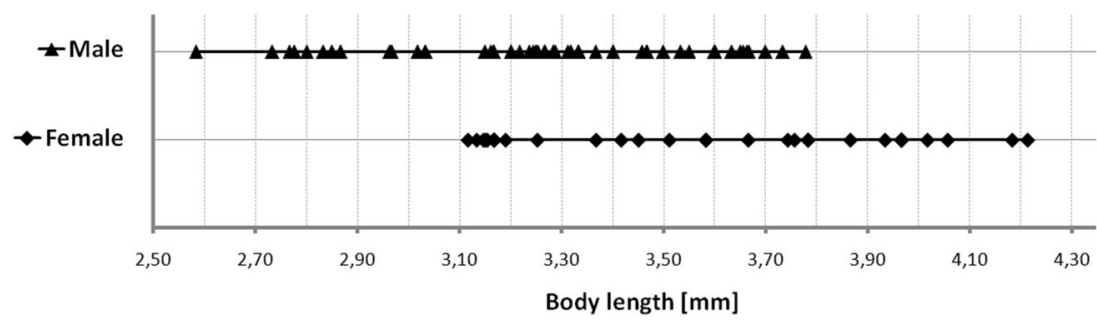

first tibia; and (9) length of the funicle, were examined and measured on all 97 weevil bodies under an optical stereomicroscope (Olympus SZ11). Measurements were made by using a calibrated ocular micrometre at $\times 60$ magnification.

We also examined selected non-morphometric characters such as the sculpturing on the rostrum and pronotum, shape and sculpturing of the elytra and shape of abdominal sternites to check their usefulness in sex determination.

The presence/absence of the notch in the ventral portion of the 8th abdominal sternite of the male, as described by Agee (1964) and Sappington \& Spurgeon (2000), as a sex distinguishing structure on $A$. grandis was also observed, as well as the differences of the 7th and 8th abdominal segments recorded as being sex related in $A$. pomorum (Duan et al 1999).

Finally, all studied specimens were dissected to ascertain their sex and stored in separate, numbered tubes. Body length was calculated as the sum of rostrum, head, pronotum and elytra length. The differences in body characters between males and females were analysed using $t$ tests and regarded as significantly different at $P<0.05$.

Contrasting male and female photos, illustrating various body structures (whole body, rostrum at base-apex, rostrum at base-antenna (metarostrum), differences in the 4th and 5th abdominal segments, tergal notch, antenna and olfactory sensillae), were taken with an Olympus BX63 microscope and processed by Olympus cellSens Dimension software. The specimens selected for pictures using SEM (scanning electron microscopy) were at first dried in absolute ethyl alcohol (99.8\%), rinsed in acetone and then gold-plated. A TESCAN Vega 3 SEM was used for the examination of selected structures. All these specimens were deposited in the collection of the Department of Zoology and Nature Protection, Maria Curie-Skłodowska University (Lublin, Poland).

\section{Results}

Morphological comparisons between sexes

\section{Characters with significant sex-related differences}

Total body length. Female body length was significantly greater (mean $=3.581 \mathrm{~mm}, n=32$ ) than male body length (mean $3.254 \mathrm{~mm}, n=65)$ in all specimens $(n=97)\left(t_{(95)}=\right.$ 4.911, $P<0.001$ ) (Fig. 1, Table 1).

Elytra shape and morphometrics. Elytra were both significantly longer $($ mean $=1.511 \mathrm{~mm})\left(t_{(95)}=2.382, P=0.022\right)$ and wider $(1.111 \mathrm{~mm})\left(t_{(95)}=2.903, P=0.005\right)$ in females than in males (length $=1.422 \mathrm{~mm}$ and width $=1.043$ ) (Table 1$)$, (Figs 2a-d) and were shaped somewhat differently, almost
Table 1 Anthonomus santacruzi Hustache, 1924, sex determination character measurements between all male and female specimens (mean \pm $\mathrm{SD}, n=97$ )

\begin{tabular}{llllll}
\hline Character & $\begin{array}{l}\text { Females }(\mathrm{mm}) \\
(n=32)\end{array}$ & $\begin{array}{l}\text { Female range } \\
(\mathrm{mm})\end{array}$ & $\begin{array}{l}\text { Males }(\mathrm{mm}) \\
(n=65)\end{array}$ & $\begin{array}{l}\text { Male range } \\
(\mathrm{mm})\end{array}$ & $P$ value \\
\hline $\begin{array}{l}\text { Rostrum length } \\
\text { (base-apex) }\end{array}$ & $0.928 \pm 0.09$ & $0.75-1.08$ & $0.809 \pm 0.065$ & $0.7-0.933$ & $<0.001$ \\
$\begin{array}{c}\text { Metarostrum } \\
\text { (base-antenna) }\end{array}$ & $0.455 \pm 0.062$ & $0.25-0.55$ & $0.363 \pm 0.049$ & $0.25-0.477$ & $<0.001$ \\
$\begin{array}{l}\text { Pronotum length } \\
\text { Pronotum width }\end{array}$ & $0.489 \pm 0.047$ & $0.417-0.583$ & $0.485 \pm 0.044$ & $0.383-0.6$ & 0.668 \\
Elytra length & $0.689 \pm 0.069$ & $0.55-0.833$ & $0.674 \pm 0.065$ & $0.5-0.83$ & 0.284 \\
Elytra width & $1.511 \pm 0.173$ & $1.167-1.767$ & $1.422 \pm 0.178$ & $0.967-1.75$ & 0.022 \\
First tarsus length & $1.111 \pm 0.132$ & $0.833-1.433$ & $1.043 \pm 0.097$ & $0.8-1.217$ & 0.005 \\
First tibia length & $0.299 \pm 0.055$ & $0.2-0.383$ & $0.294 \pm 0.056$ & $0.2-0.483$ & 0.658 \\
Funiculus length & $0.526 \pm 0.1$ & $0.33-0.8$ & $0.529 \pm 0.067$ & $0.367-0.667$ & 0.841 \\
Total body length & $0.492 \pm 0.057$ & $0.383-0.633$ & $0.479 \pm 0.053$ & $0.35-0.6$ & 0.279 \\
Notch & $3.581 \pm 0.365$ & $3.117-4.213$ & $3.254 \pm 0.277$ & $2.583-3.778$ & $<0.001$ \\
\hline
\end{tabular}

${ }^{*} P$ values in italic indicate significant differences between male and female body characters at $P<0.05$ ( $t$ test). 

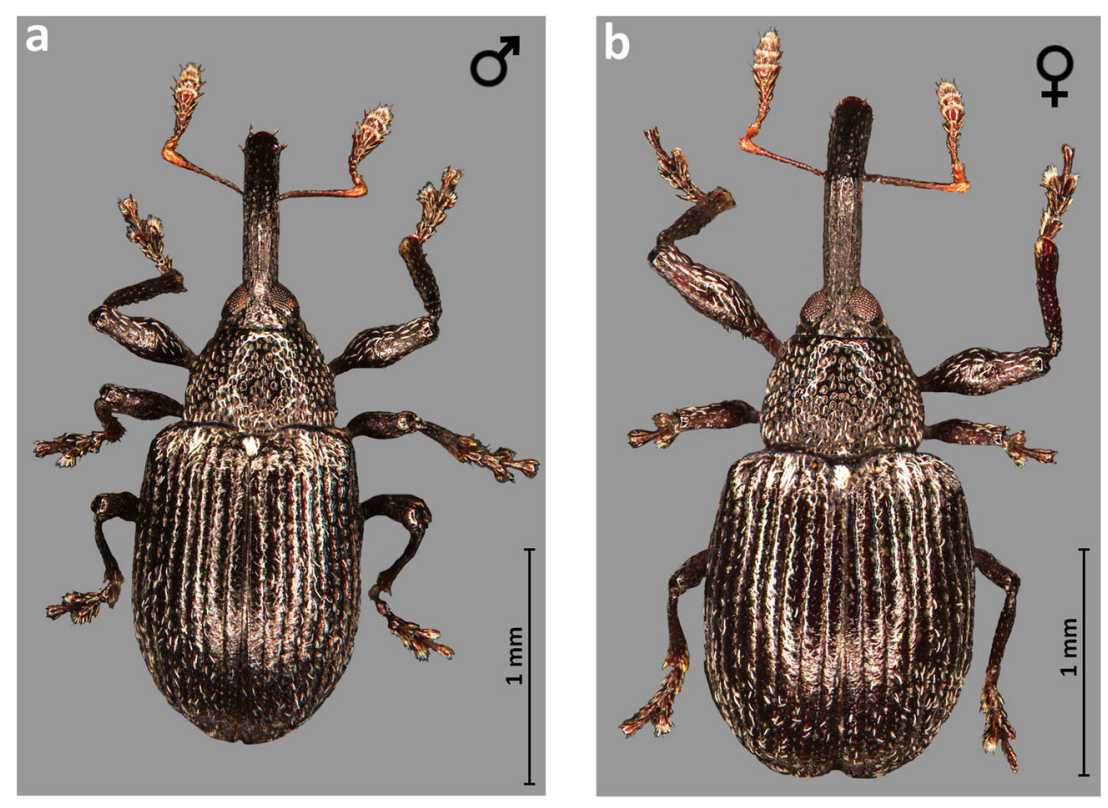

Fig 2 Anthonomus santacruzi Hustache, 1924, habitus: a dorsal view of male; $\mathbf{b}$ dorsal view of female; c ventral view of male; $\mathbf{d}$ ventral view of female (a-d
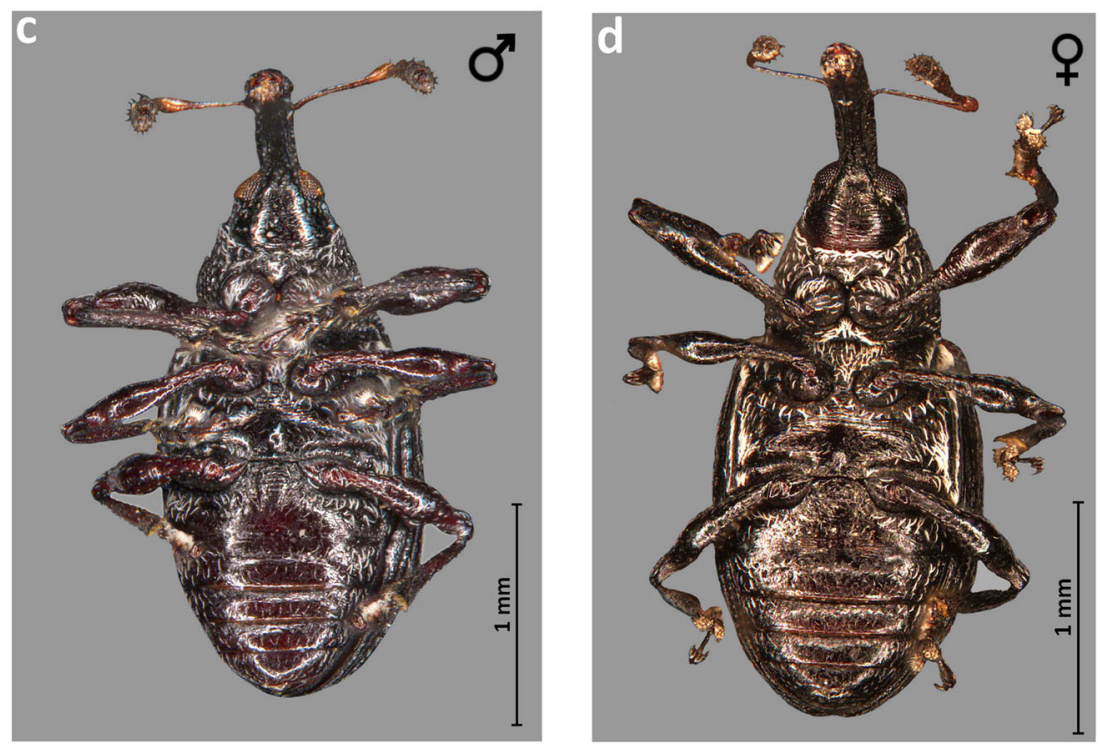
optical microscope pictures).

parallel on males vs. slightly enlarged on the distal part on females. The shape of elytra in males is variable, could be either almost subquadrate or distinctly elongate (Figs 2a- $d, 3$ and $4 a-d)$.

Rostrum morphology. The female rostrum length was significantly longer than the male rostrum in both, the total length $\left(t_{(95)}=7.416, P<0.001\right)$ and length of metarostrum $\left(t_{(95)}=\right.$ 7.943, $P<0.001$ ) (Table 1). The female metarostrum was almost half the length of the total rostrum length while for males it was only $40 \%$ of the total rostrum length (Table 1 ). On males, the surface of the metarostrum was distinctly ridged, with visible, longitudinal ridges, with the apical part densely covered by relatively coarse punctures, less shiny
Fig 3 Length/width ratio of elytra in male and female Anthonomus santacruzi Hustache, 1924.

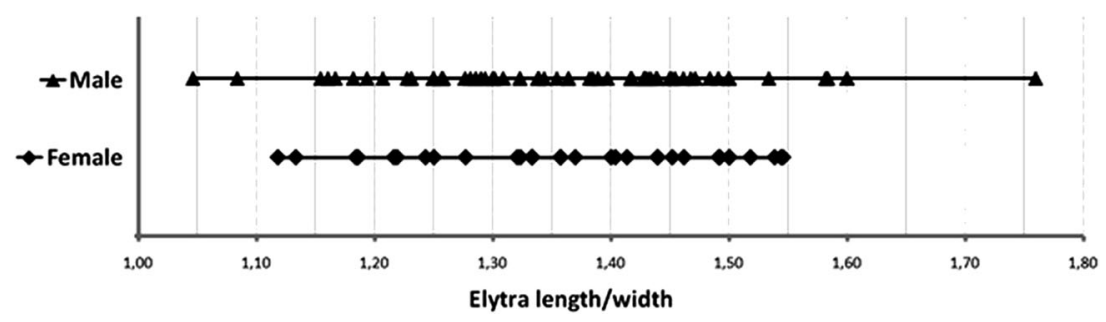


Fig 4 Anthonomus santacruzi Hustache, 1924, habitus: a dorsal view of male; $\mathbf{b}$ dorsal view of female; c ventral view of male; $\boldsymbol{d}$ ventral view of female (a-d SEM pictures).
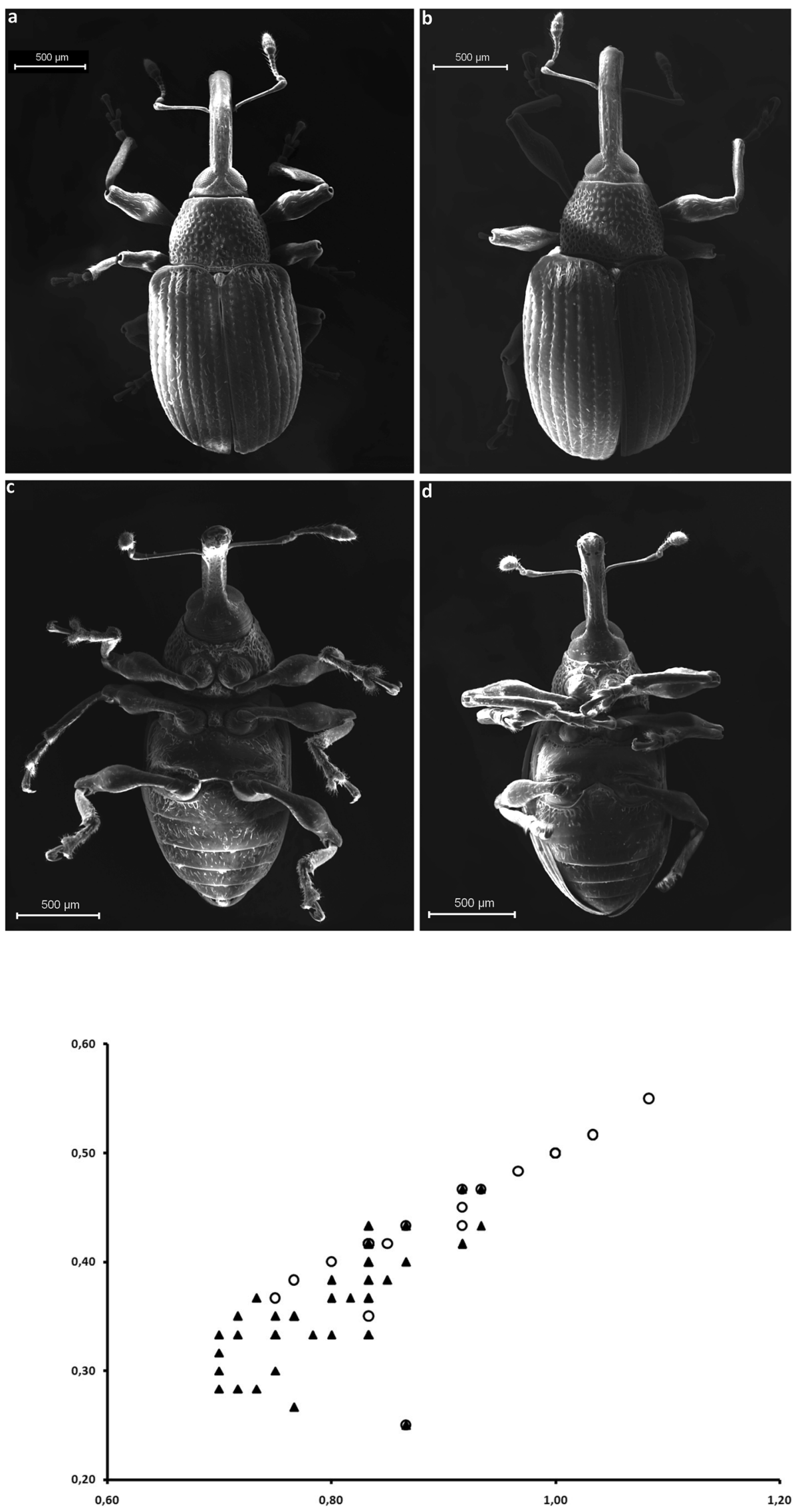

Fig 5 The relationship between the total length of the rostrum and length of the metarostrum, between male and female ( $X$-axis - length of rostrum, Y-axis length of metarostrum; black triangle - male, white circle female) Anthonomus santacruzi Hustache, 1924. 


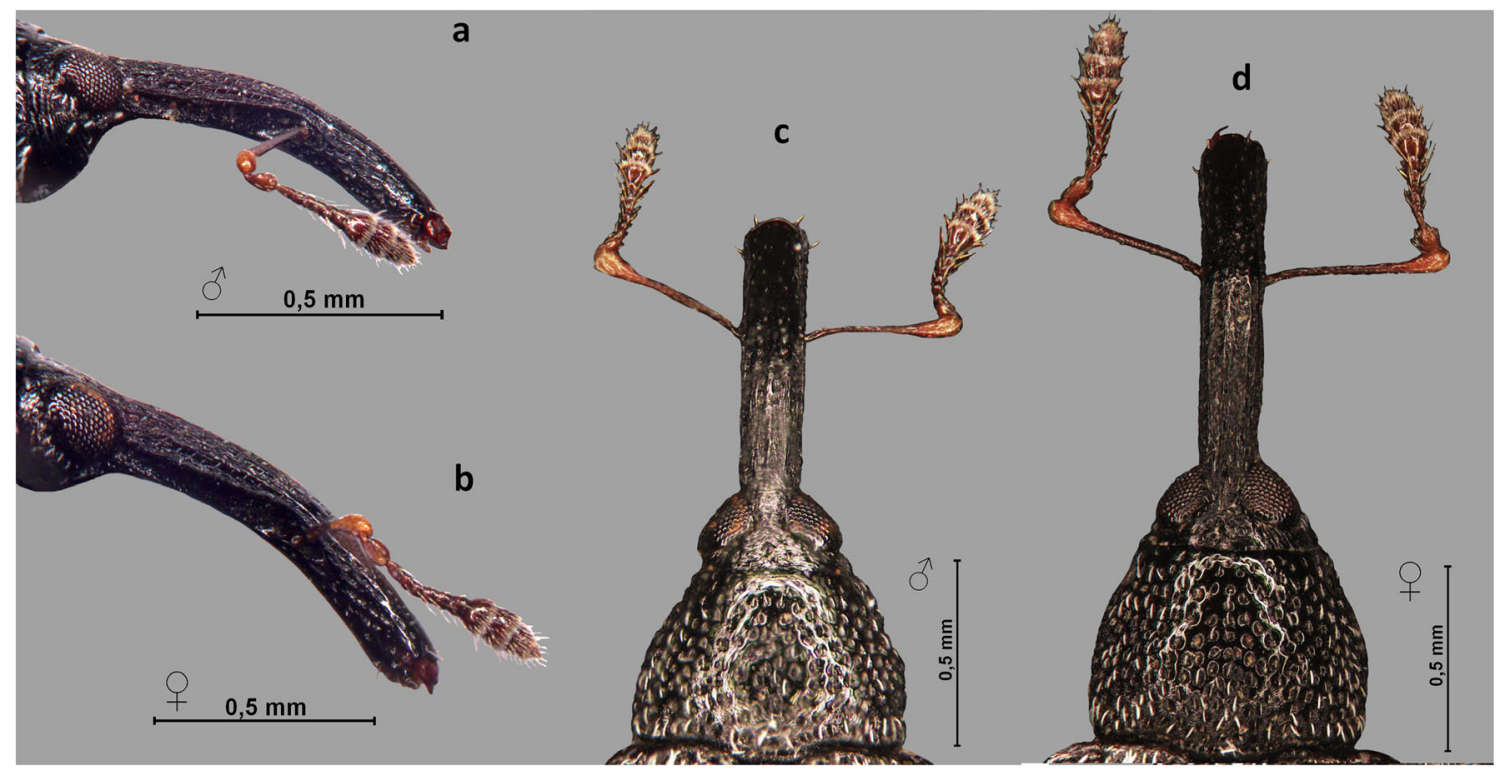

Fig 6 Anthonomus santacruzi Hustache, 1924, rostrum and pronotum: a lateral view of male; b lateral view of female; $\mathbf{c}$ dorsal view of male; $\mathbf{d}$ dorsal view of female (a-d optical microscope pictures).

than the female. On females, the surface of metarostrum has fine, longitudinal ridges; apical part of rostrum glabrous, shiny, with sparse, shallow punctures, being relatively more smooth and shiny. Thus the female rostrum was found to be longer and smoother than the male rostrum, especially the apical part (Figs 5, 6a-d and 7a, b).

Fourth and fifth abdominal segments. The 4 th and 5 th abdominal segments were clearly separated in males (Figs $8 a, c$ and $9 a, c, e$ ), whilst they were fused together in females (Figs $8 b, d$ and $9 b, d, f)$. In addition, the male ventral side (1st-7th sternites) appears to have more hairs (Fig 8a), being slightly concave and shiny (Fig 8c), while the female ventral side (1st7 th sternites) appears to be less hairy (Fig 8b), flat or slightly convex and dull (Figs 8b, d).

Notch (7th and 8th tergite and sternite). Anthonomus santacruzi males have eight visible dorsal abdominal segments, while females have seven visible segments. The notch, on the posterior edge of the 8th tergite was distinct in males (Table 1). The anterior border of the 7 th tergite was thin and slightly rounded in females (Figs $9 b, d, f)$. In contrast, the anterior border of the 8th tergite in males was distinctively augmented and notched (Figs 9a, c, e).
Fig 7 Anthonomus santacruzi Hustache, 1924, rostrum, dorsal view with magnification of the metarostrum and the apical part (SEM pictures): a male; $\mathbf{b}$ female.
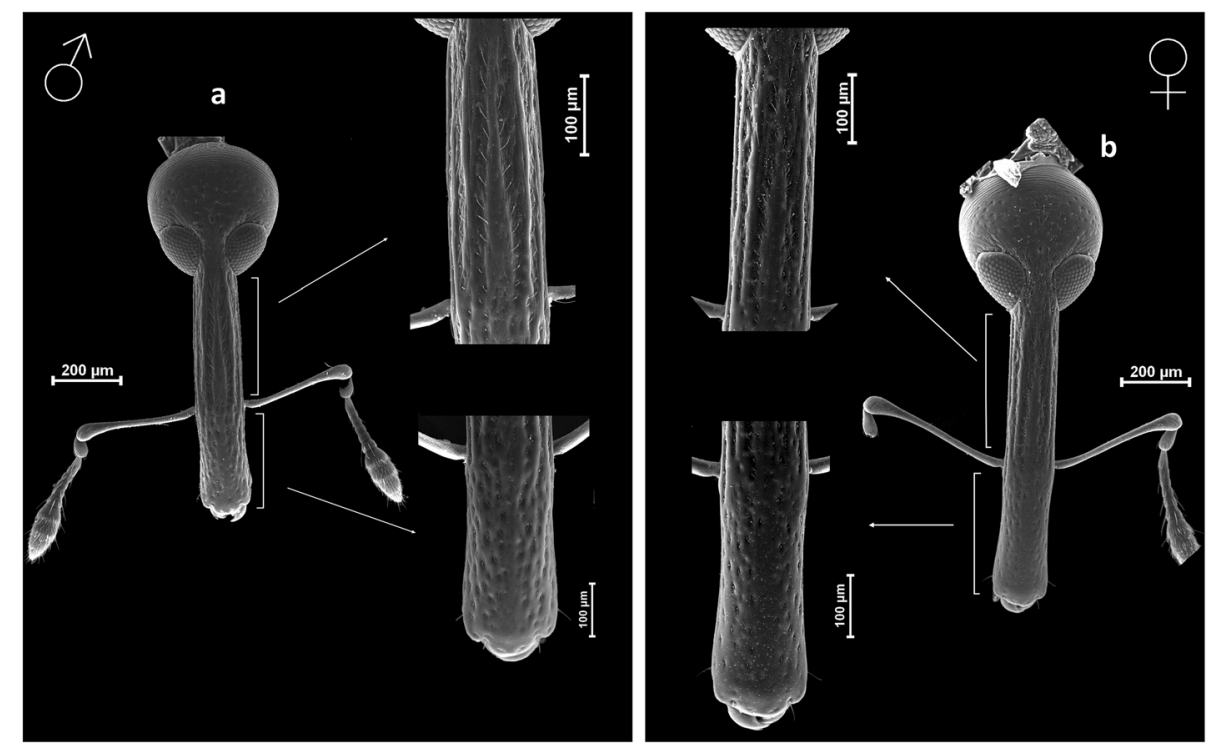

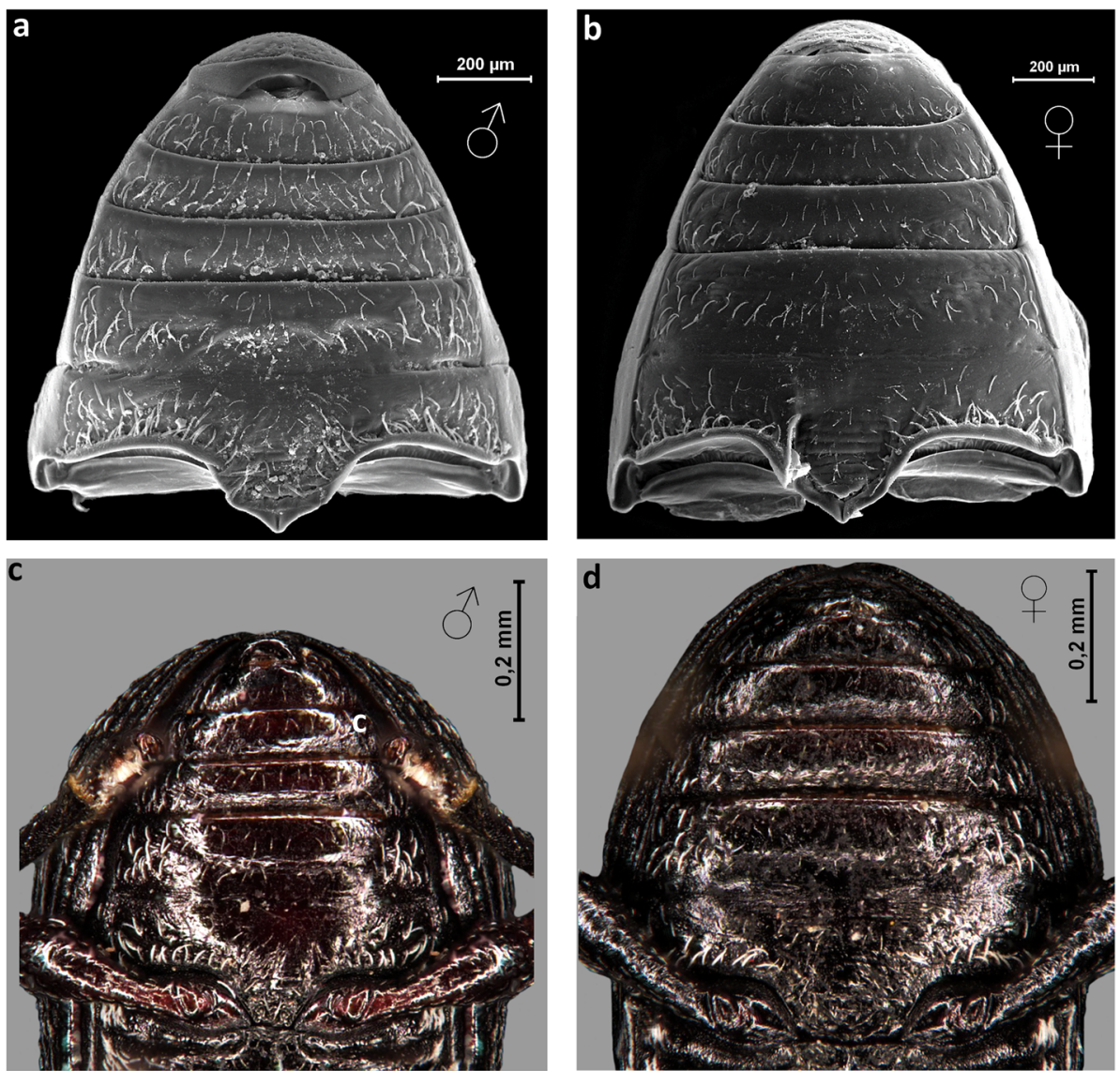

Hustache, 1924, ventral view of abdominal segments: male $(\mathbf{a}, \mathbf{c})$ female (b, d) (a, b SEM pictures; c, $\mathbf{d}$ optical microscope pictures).

\section{Other characters with sex-related differences}

Pronotum shape and morphometrics. On the lateral sides of the female pronotum (between the middle and base) it appears to be slightly curved, being "pear-shaped", whereas in the males it is straight, being almost parallel. Pronotum length and width (Fig 10), showed no significant differences between the sexes in all specimens $(n=97)$ (length: $t_{(95)}=$ $0.431, P=0.668$, width: $t_{(95)}=1.077, P=0.284$ ) (Table 1), but were still visible in some examined samples (Figs $2 a, b$ and $6 c, d)$.

Localisation of eyes. On females (in lateral view), the eyes do not stand out from the dorsal outline of the head, whereas in males (in lateral view) the eyes protrude slightly from the outline of the head (Figs 6a, b).

\section{Selected characters without sex-related differences}

Funicule length $\left(t_{(95)}=1.089, P=0.279\right)$, first tarsus length $\left(t_{(95)}=0.444, P=0.658\right)$ and first tibia length $\left(t_{(95)}=0.202\right.$, $P=0.841$ ) showed there were no significant differences between A. santacruzi sexes (Table 1; Fig 11).

\section{Discussion}

Many researchers (e.g. Smreczyński 1972) reported distinct similarities between males and females of Anthonomini as well as rather less visible differences, e.g., relative length of rostrum (shorter on male, longer on female), the insertion of the scape (scape being situated closer to the apex of the rostrum in males than on females) and the sculpture of rostrum (distinctly ridged and matt in males and more smooth and shiny on females).

Even though total rostrum length (base-apex), length of metarostrum (antenna-apex), elytral length and width and total body length were significantly different between the sexes, they cannot be used to completely distinguish $A$. santacruzi males and females, as there is a broad overlap in these characters between the sexes. However, these disparities can be used for initial separation of sexes (George et al 2015).

Use of rostrum length was reported to be easy and has been widely used in distinguishing the sexes in selected Anthonomus species in the last century, but regarded as subjective because the characters were deemed subtle, variable and relative rather than absolute (Smreczyński 1972, Sappington \& Spurgeon 2000). 

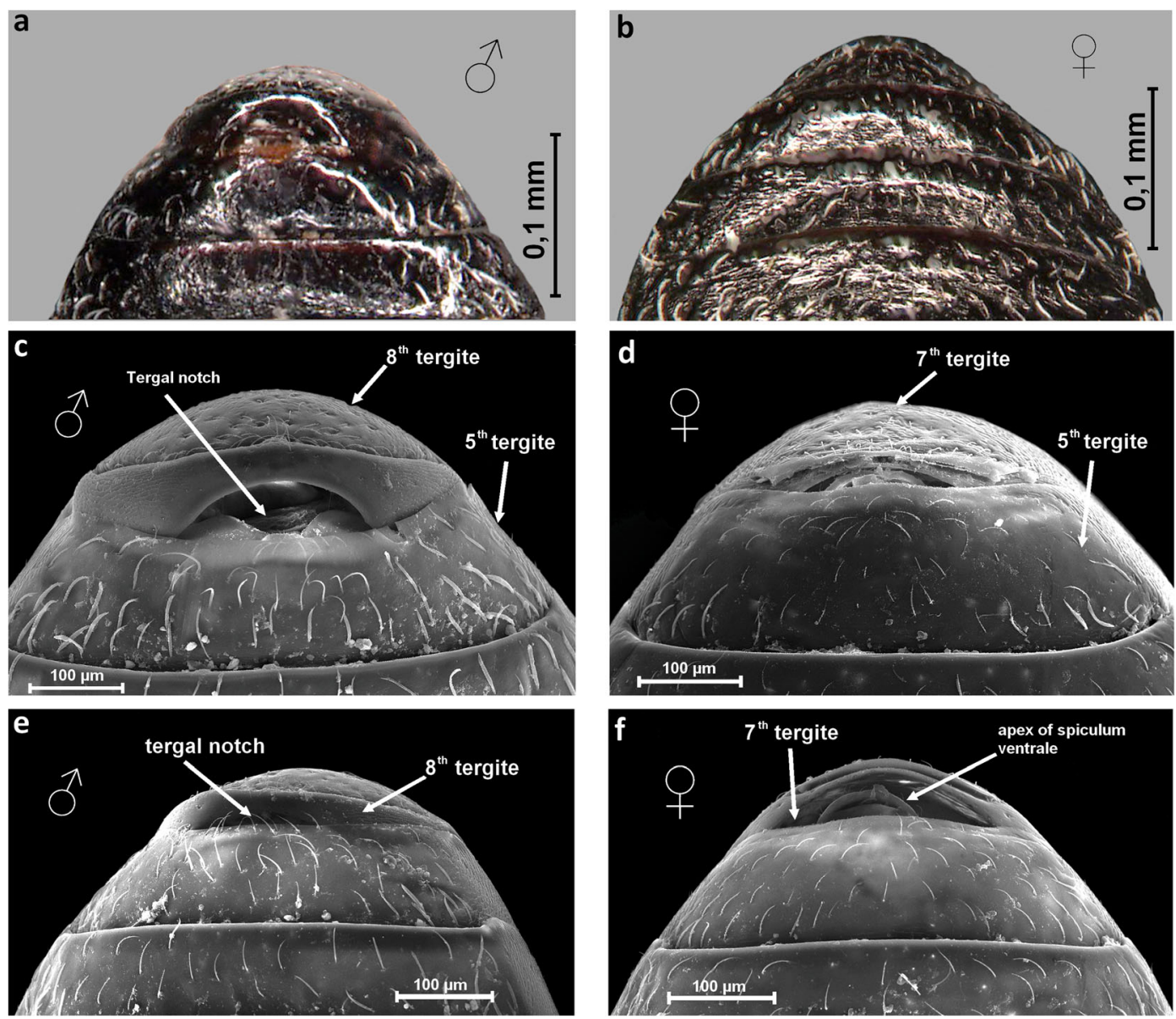

Fig 9 Anthonomus santacruzi Hustache, 1924, ventral view of abdominal segments: male (a, c, e), female (b, d, f) (a, b optical microscope pictures; c-f SEM pictures).

However, the tergal notch was found to be the most useful body character in separating $A$. santacruzi sexes. All $A$. santacruzi males $(n=65)$ were successfully separated from all females $(n=32)$ using this notch. This supports Sappington \& Spurgeon (2000) that if performed correctly, the notch method of separating males and females is $100 \%$ accurate. According to the article mentioned above, distinguishing sexes in insects using the notch is easy, to the extent that even a novice, who might mistake the 7th female tergite for the notch, will usually not make that mistake within the first hour of training in $A$. grandis sexing. The same, mentioned above authors, added that sexing using the notch is not as slow as generally perceived, and experienced personnel may process $>200-300$ weevils in an hour.

Just like $A$. grandis, A. santacruzi males have eight dorsal abdominal segments while females have seven visible segments. However, this difference has not been used to distinguish sexes because it involves separating the elytra which the weevils keep tightly closed (Sappington \& Spurgeon 2000).

Unfortunately, some of the body structure differences between the sexes, such as dorsal abdominal segments and genitalia, cannot be applied when dealing with live specimens as they can only be viewed using invasive procedures that may injure the specimens. Overall, the abdominal notch
Fig 10 Length/width ratio of pronotum in male and female Anthonomus santacruzi Hustache, 1924.

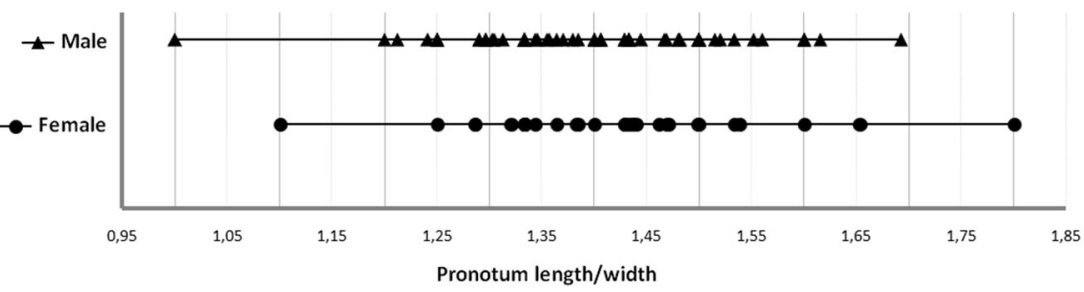


Fig 11 The range of variation in length of the funicle, first tibia and fore tarsus, between male and female Anthonomus santacruzi Hustache, 1924.

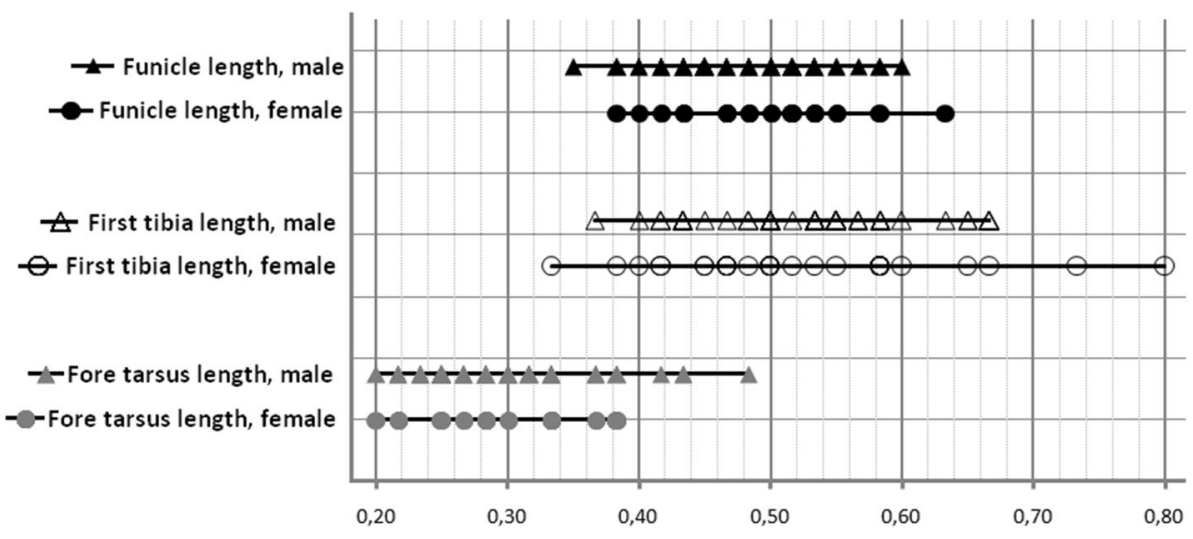

Table 1), were rostrum length, elytra length, presence of notch and total body length. Some of these characters are related to the structure of the cuticle (especially of the rostrum) and shape of some body parts (rostrum, abdominal sternites) or arise from different proportions of the body parts.

2. There were also some "subsidiary characters". We add here other features such as the shape of the pronotum and the dorsal localisation of eyes, which due to individual variability sometimes make them difficult to use to distinguish between sexes.

Taking into consideration other groups of Curculionidae, Baba \& Yoneda (2000) observed that differences between the sexes depended on the density and shape of scales on the metasternum of the West Indian sweetpotato weevilEuscepes postfasciatus Fairmaire, 1849, while Grocholski et al (1976) observed sex-related differences in patterns of bristles on the last abdominal sternite of bark beetles in the genus Hylastes (Erichson, 1836). Further, the presence of an elongated depression on the abdominal sternites of males was noted on Hylobius radicis (Buchanan, 1935) by Wilson (1966) and on $H$. warreni (Wood, 1957) by Öhrn et al (2008), as well on the cocoa weevil borer-Pantorhytes szentivanyi (Marshall, 1957) by Hassan (1973). Consequently, Santos et al (2018) reported differences in the shape of the abdominal tergites between males and females of Ozopherus muricatus Pascoe, 1872. Hence, external dimorphism in weevils shows fairly large variability across species, and thus, further study on this topic is required.

The male-biased sex ratio of 0.67 (one female $(n=32)$ to two ( $n=65$ ) males) in the sampled weevils used in this study might be a result of protandry (i.e. early male emergence). The biased sex ratio has been found to be promoted by climate alterations in the timing of rainfall and/or extreme temperatures (e.g. the Mediterranean acorn weevil Curculio elephas (Gyllenhal, 1836) (Coleoptera: Curculionidae) (Bonal et al 2015). Protandrous behaviour and sex ratios in general have not previously been reported in the genus Anthonomus 
(except for sex ratios in A. grandis, e.g. Greenberg et al 2004) and may warrant a detailed investigation. Protandry has the advantage of preserving the effective population size as the females will not be male limited, and unlike a female-biased sex ratio, it will not be detrimental to population genetic diversity. However, strongly biased adult sex ratios influence the risk of extinction or population collapse (Greenberg et al 2004). Hence, the optimal sex ratios of insects released in biocontrol programs to maximize their effectiveness need more research in general.

Authors' Contributions Idea and conceptualization: Archbold Sasa. Material collection: Archbold Sasa. Material preparation: Rafał Gosik. Design: Archbold Sasa, Rafał Gosik. Data and statistical analysis: Archbold Sasa, Miłosz A. Mazur. Data acquisition and interpretation: Rafał Gosik. Writing-original draft preparation: Archbold Sasa, Rafał Gosik, Ed T.F. Witkowski, Marcus J. Byrne, Miłosz A. Mazur. Writingreview and editing: Archbold Sasa, Rafał Gosik, Ed T.F. Witkowski, Marcus J. Byrne, Miłosz A. Mazur. Visualization: Rafał Gosik, Miłosz A. Mazur. Funding acquisition: Rafał Gosik, Ed T.F. Witkowski, Marcus J. Byrne, Miłosz A. Mazur.

Electronic supplementary material The online version of this article (https://doi.org/10.1007/s13744-020-00795-6) contains supplementary material, which is available to authorized users.Funding Information This study was funded by the South African Department of Environmental Affairs and the Agricultural Research Council (ARC).

Open Access This article is licensed under a Creative Commons Attribution 4.0 International License, which permits use, sharing, adaptation, distribution and reproduction in any medium or format, as long as you give appropriate credit to the original author(s) and the source, provide a link to the Creative Commons licence, and indicate if changes were made. The images or other third party material in this article are included in the article's Creative Commons licence, unless indicated otherwise in a credit line to the material. If material is not included in the article's Creative Commons licence and your intended use is not permitted by statutory regulation or exceeds the permitted use, you will need to obtain permission directly from the copyright holder. To view a copy of this licence, visit http://creativecommons. org/licenses/by/4.0/.

\section{References}

Agee HR (1964) Characters for determination of sex of the boll weevil. J Econ Entomol 57:500-501

Ancona S, Dénes FV, Krüger O, Székely T, Beissinger SR (2017) Estimating adult sex ratios in nature. Philos T R Soc B 372:20160313

Baba K, Yoneda M (2000) Sexual difference of morphological characters of scales on metasternum of West Indian sweet potato weevil, Euscepes postfasciatus Fairmaire. Jpn J Appl Entomol Z 44:54-56

Bená D, Vanin SA (2013) Description of the immature stages of the weevil Anthonomus vis Clark (Coleoptera, Curculionidae), inquiline into the gall of Leandra aurea (Melastomataceae). Re Bras Entomol 57:367-373

Bonal R, Hernández M, Espelta JM, Muñoz A, Aparicio JM (2015) Unexpected consequences of a drier world: evidence that delay in late summer rains biases the population sex ratio of an insect. $\mathrm{R}$ Soc Open Sci 2:150198

Chacón Madrigal EJ, Johnson TM, Hanson P (2012) The life history and immature stages of the weevil Anthonomus monostigma Champion (Coleoptera: Curculionidae) on Miconia calvescens DC (Melastomataceae). P Entomol Soc Wash 114:173-185

Choe JC, Crespi BJ (1997) The evolution of mating systems in insects and arachnids. Cambridge University Press, 397pp

Clark WE, Burke HR (1996) The species of Anthonomus Germar (Coleoptera: Curculionidae) associated with plants in the family Solanaceae. Southwest Entomol 19:1-114

Cowie BW, Venter N, Witkowski ETF, Byrne MJ, Olckers T (2018) A review of Solanum mauritianum biocontrol: prospects, promise and problems: a way forward for South Africa and globally. BioControl 63: 475-491

Dinuă A, Bunescu H, Bodis I (2009) Contributions to the knowledge of morphology of the granary weevil (Sitophilus granarius L.), major pest of the stored cereals. Bulletin of University of Agricultural Sciences and Veterinary Medicine. Agriculture 66:59-66

Duan JJ, Weber DC, Hirs BA, Dorn S (1999) A new character for sex differentiation of adults of Anthonomus pomorum L. (Coleoptera: Curculionidae). J Appl Entomol 123:319-320

English K, Olckers T (2018) Abundance across seasons and early impact of the florivorous weevil Anthonomus santacruzi (Curculionidae) on Solanum mauritianum (Solanaceae) in KwaZulu-Natal Province, South Africa. Biol Control 121:175-182

Foelker CJ, Hofstetter RW (2014) Heritability, fecundity, and sexual size dimorphism in four species of bark beetles (Coleoptera: Curculionidae: Scolytinae). Ann Entomol Soc Am 107:143-151

Fowler S (2014) Lace bug does best in the shade. Weed Biocontrol Newsletters, 69. https://www.landcareresearch.co.nz/publications/ newsletters/biological-control-of-weeds/issue-69/lace-bug-doesbest-in-shade/Accessed 29 Mar 2019

George J, Morse WC, Lapointe SL (2015) Morphology and sexual dimorphism of the weevil Myllocerus undecimpustulatus undatus (Coleoptera: Curculionidae). Ann Entomol Soc Am 108:325-332

Gosik R, Sasa A, Witkowski ETF (2017) Description of the mature larva and pupa of Anthonomus santacruzi Hustache (Coleoptera, Curculionidae), a biological control agent of Solanum mauritianum Scop. (Solanaceae), and remarks about its biology. Zootaxa 4294: 545-558

Greenberg SM, Sappington TW, Coleman RJ (2004) Population dynamics of overwintering boll weevils, Anthonomus grandisgrandis (Boheman) in the Lower Rio Grande Valley of Texas. Entomology Presentations, Posters and Proceedings 4.https://lib.dr.iastate.edu/ ent_conf/4. Accessed 20 Dec 2019

Grocholski J, Michalski J, Nowak W (1976) Notes on intraspecific variation and sexual dimorphism of some Palaearctic species in the genus Hylastes Er. (Col., Scolytidae). Acta Zool Cracov 21:553-584

Hakizimana S, Olckers T (2013) Should the flower bud weevil Anthonomus santacruzi (Coleoptera: Curculionidae) be considered for release against the invasive tree Solanum mauritianum (Solanaceae) in New Zealand? Biocontrol Sci Tech 23:197-210

Hassan E (1973) The determination of sexes of the cacao weevil borer Pantorhytes Szentivanyi Marshall (Coleoptera: Curculionidae). Papua New Guinea Agri J 24:46-48

King AM, Brudvig R, Byrne MJ (2011) Biological control of dense-thorned bitter apple, Solanum sisymbriifolium Lam. (Solanaceae), in South Africa. Afr Entomol 19:427-433

Kovarik PBHR (1983) Sexual dimorphism of tarsal claws in Anthonomine weevils (Coleoptera: Curculionidae). Entomol News 94:37-40

Łukowski A, Mąderek E, Giertych MJ, Karolewski P (2015) Sex ratio and body mass of adult herbivorous beetles depend on time of occurrence and light conditions. PLoS One 10:e0144718

Mkhize NL, Olckers T (2019) Persistence of the flowerbud weevil Anthonomus santacruzi in optimal versus marginal areas: implications 
for the biological control of the invasive tree Solanum mauritianum in South Africa. Biocontrol Sci Tech 29:649-660

Öhrn P, Klingenberg M, Hopkins G, Björklund N (2008) Two nondestructive techniques for determining the sex of live adult Hylobius warreni. Can Entomol 140:617-620

Olckers T (2003) Assessing the risks associated with the release of a flower bud weevil, Anthonomus santacruzi, against the invasive tree Solanum mauritianum in South Africa. Biol Control 28:302-312

Olckers T (2011) Biological control of Solanum mauritianum Scopoli (Solanaceae) in South Africa: will perseverance pay off? Afr Entomol 19:416-426

Ramalho FS, Jesus FMM (1988) Distribution of boll weevil (Anthonomus grandis Boheman) eggs within cotton plants. Trop Agric 65:245-248

Rodríguez Leyva E, Stansly PA, Schuster DJ, Bravo Mosqueda E (2007) Diversity and distribution of parasitoids of Anthonomus eugenii (Coleoptera: Curculionidae) from Mexico and prospects for biological control. Fla Entomol 90:693-702

Santos NL, Silva KB, Lopes de Oliveira ER, Goulart HF, Santana AEG, Guzzo EC (2018) Sexual dimorphism in Ozopherus muricatus Pascoe, 1872 (Coleoptera: Curculionidae). Arq Inst Biol 85:1-5

Sappington TW, Spurgeon DW (2000) Preferred technique for adult sex determination of the boll weevil (Coleoptera: Curculionidae). Ann Entomol Soc Am 93:610-615
Smreczyński S (1972) Ryjkowce-Curculionidae: Podrodzina Curculioninae. Klucze do Oznaczania Owadów Polski; Państwowe Wydawnictwo Naukowe: Warszawa, Poland, p 195

Speranza S, Colonnelli E, Garonna AP, Laudonia S (2014) First record of Anthonomus eugenii (Coleoptera: Curculionidae) in Italy. Fla Entomol 97:844-845

Tabadkani SM, Ashouri A, Rahimi Alangi V, Fathi Moghaddam M (2012) When to estimate sex ratio in natural populations of insects? A study on sex ratio variations of gall midges within a generation. Entomol Sci 16:54-59

Wilson LF (1966) A way to distinguish sex of adult Hylobius weevils in the field. The Can Entomol 98:1118-1119

Witkowski ETF, Garner RD (2008) Seed production, seed bank dynamics, resprouting and long-term response to clearing of the alien invasive Solanum mauritianumin a temperate to subtropical riparian ecosystem. S Afr J Bot 74:476-484

Publisher's Note Springer Nature remains neutral with regard to jurisdictional claims in published maps and institutional affiliations. 